\title{
Cytokine Antibody Arrays: A Useful Tool in Biotechnology for the Screening of Specific Biomarkers in Eyes Diseases
}

\author{
Josep M Fernández Novelli*, Laia García Murias ${ }^{1}$, Lina Trujillo² and Joan E Rodríguez Gill ${ }^{2}$ \\ ${ }^{1}$ Department of Biochemistry and Molecular Biomedicine, University of Barcelona, Spain \\ ${ }^{2}$ Department of de Medicinay Cirugía Animales, Facultad de veterinaria, Spain
}

Submission: November 12, 2018; Published: January 25, 2019

*Corresponding author: Josep M Fernández Novell, Department of Biochemistry and Molecular Biomedicine, University of Barcelona, Diagonal 643 Edifici Prevosti, planta -2, E-08028 Barcelona, Spain

\begin{abstract}
Some of the eye diseases may require invasive methods like surgical biopsy, or less invasive but with a limited diagnostic accuracy like fine needle aspiration biopsy. Tears could be a non-invasive method to obtain samples to analyzing eye diseases. Antibody arrays, mini array of protein, is a recently established proteomic biotechnology providing unique opportunities for various applications, such as protein expression profiling, biomarker discovery, disease diagnostics, prognostics and more. The use of mini arrays of protein to analyze the presence of inflammation proteins in tears may represent a non-invasive technique which can be used to identify potential biomarkers of eye diseases. It can open a new perspective to discover new molecules, so as to use them as possible targets for the development of innovative pharmacological approaches.
\end{abstract}

Keywords: Tear proteins, antibody array, potential biomarkers, ocular diseases

\section{Introduction}

Antibody arrays is a recently established proteomic technology providing unique opportunities for various applications, such as protein expression profiling, biomarker discovery, disease diagnostics, prognostics, evidence-based therapy selection, and disease monitoring [1]. Moreover, many academic research laboratories and commercial biotechnology companies are starting to apply antibody arrays in the field of drug discovery [2] Protein arrays are an excellent platform that allow for the screening and scanning of biomarkers with highthroughput capacity, high sensitivity, and high specificity. One of the advantages of antibody array technology is its capability of profiling proteins in non-fractionated biological samples. Cytokines, broadly defined as secreted cell-cell signaling proteins, play important roles in a wide range of physiological processes, such as inflammation, innate immunity, apoptosis, angiogenesis, cell growth and differentiation $[3,4]$.

As one of the most exciting emerging technologies, protein array provides a versatile and robust platform in cancer proteomics research because it shows tremendous advantages of miniaturized features, high throughput, and sensitive detections in last decades. Several studies are currently using protein array technologies for biomarker discovery in diseases like lupus and cancer $[5,6]$. Although, enormous untapped potential for protein array utilization in eye diseases still exists. In ocular diseases, the early diagnosis in very important in order to prevent several ocular damage and the decrease of the visual acuity and other permanent consequences [7], because there are important biochemical changes in the composition of the tear than usually appear before the patient be able to note any symptom [8].

Some of the ocular diseases, especially tumours, may require invasive methods like surgical incision o excision biopsy [9], or less invasive but with a limited diagnostic accuracy like fine needle aspiration biopsy [10]. Tears could be an easy sample to analyzing eye diseases. This way, we will demonstrate that this technique, antibody mini array, and tears can be used as a non-invasive screening technique in eyes diseases. The use of arrays to analyze the presence of inflammation proteins in tears may represent a great opportunity to diagnose an early ocular disease and why not, predict and avoid the emergency of permanent damage which usually is caused by a late or wrong diagnosis of ocular diseases.

\section{Materials and Methods}

Tear samples were obtained from each eye of one healthy subject through emotional stimulus and were collected with a sterile Pasteur pipette directly from the lateral eye can thus so as to avoid the tear reflex as much as possible. The subject had no previous ophthalmic disease, did not have any ocular symptoms and was not contact lens users. Written consent was obtained. 
After determining protein concentration of tear samples by the Bradford technique [11] using a commercial kit (Bio-Rad Protein Assay Dye Reagent; Bio-Rad Laboratories Headquarters, Hercules, Table 1: All consumables used in this study were obtained from Merck (Barcelona, Spain).

\begin{tabular}{|c|c|c|c|c|c|c|c|c|c|c|c|c|}
\hline & A & B & C & D & E & F & G & H & I & J & K & L \\
\hline 1 & POS & POS & NEG & NEG & Activin A & Agrin & $\begin{array}{c}\text { CD 86 } \\
(87-2)\end{array}$ & $\begin{array}{c}\text { beta- } \\
\text { NGF }\end{array}$ & $\begin{array}{c}\text { CINC-1 } \\
\text { (CXCL) }\end{array}$ & CINC-2 & CINC-3 & CNTF \\
\hline 2 & $\begin{array}{c}\text { FAS Ligand } \\
\text { (TNFSF6) }\end{array}$ & $\begin{array}{c}\text { Fractatkine } \\
\text { (CX3CL1) }\end{array}$ & GM-CSF & $\begin{array}{c}\text { ICAM- } \\
\text { (CDS4) }\end{array}$ & $\begin{array}{c}\text { IFN- } \\
\text { gamma }\end{array}$ & $\begin{array}{c}\text { IL-1alpha } \\
\text { (1L- 1F1) }\end{array}$ & $\begin{array}{c}\text { IL-1 beta } \\
\text { (IL-1F2) }\end{array}$ & $\begin{array}{c}\text { IL-1R6 } \\
\text { (IL- } \\
\text { RrP2) }\end{array}$ & IL-2 & IL-4 & IL-6 & IL-10 \\
\hline 3 & IL-13 & Lep tin & LIX & $\begin{array}{c}\text { L-S } \\
\text { electin } \\
\text { (CD62) }\end{array}$ & $\begin{array}{c}\text { MCP-1 } \\
\text { (CCL2) }\end{array}$ & $\begin{array}{c}\text { MIP 3 alpha } \\
\text { (CCL20) }\end{array}$ & MMP -8 & PDGF-AA & $\begin{array}{c}\text { Prolactin } \\
\text { R }\end{array}$ & RAGE & $\begin{array}{c}\text { TCK-1 } \\
\text { (CXCL7) }\end{array}$ & $\begin{array}{c}\text { TIMP- } \\
1\end{array}$ \\
\hline 4 & TNF- alpha & VEGF-A & BLANK & BLANK & BLANK & BLANK & BLANK & BLANK & BLANK & BLANK & BLANK & P0S \\
\hline
\end{tabular}

\section{Electrophoretic analysis}

For SDS-PAGE electrophoresis [12], $8 \mu \mathrm{L}$ of tear samples were mixed with sample loading buffer nzytech ${ }^{\circledR}$ and boiled for 4 minutes. Then samples were charged in a $12.5 \%$ SDS-PAGE gel. After electrophoresis, the gel was dyed with Coomassie $®$ Brilliant Blue R-250 staining to allow the bands visualization.

\section{Mini array analysis}

Additionally, tear samples from healthy control were used to analyze some cytokines expression by mini-arrays analysis as in [3]. 34 cytokines were evaluated with a commercial antibody array system kit (RayBio® C-Series Rat Cytokine Antibody Array C2, Ray Biotech Inc., Norcross, GA, USA). Mini-array analyses were performed according to the manufacturer instructions. Finally, membranes were revealed inside the CCD camera of the Fujifilm LAS-3000 Imager. The obtained images were analyzed by ImageJ imaging analyzer [13]. This software provided a numerical expression of intensity in arbitrary units for every single analyzed spot. The protein map provides the relative position of each cytokine. Each one was analyzed by duplicate (in two separate spots) (Table 1).

Results

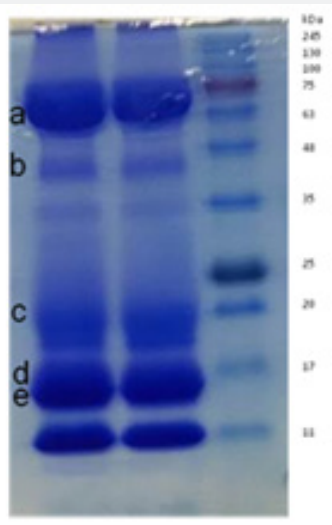

Figure 1: Protein separation by SDS-PAGE of tears. A representative image of tear samples SDS-PAGE electrophoresis shows a possible presence of a: lactoferrin $(69 \mathrm{kDa}), \mathrm{b}$ : slgA Heavy a-chain (48 kDa), c: light $\lambda$-chain $(20 \mathrm{kDa})$, d: Lipocain $(17.45 \mathrm{kDa})$ and e: Lysozym (14 kDa) in healthy tears.
CA, USA) samples were processed for electrophoretic and mini array analysis.

Electrophoretic analysis Tear samples obtained as Material and methods were studied by electrophoretic technique and separation of protein can be achieved. Results were analyzed, and we can observe in Figure 1 five representative tear protein: lactoferrin, sIgA Heavy $\alpha$-chain, light $\lambda$-chain, lipocain and lysozym and more bands, more proteins involved or not in eye diseases. Our results supported the primary proteins found in tears [14].

\section{Mini array analysis}

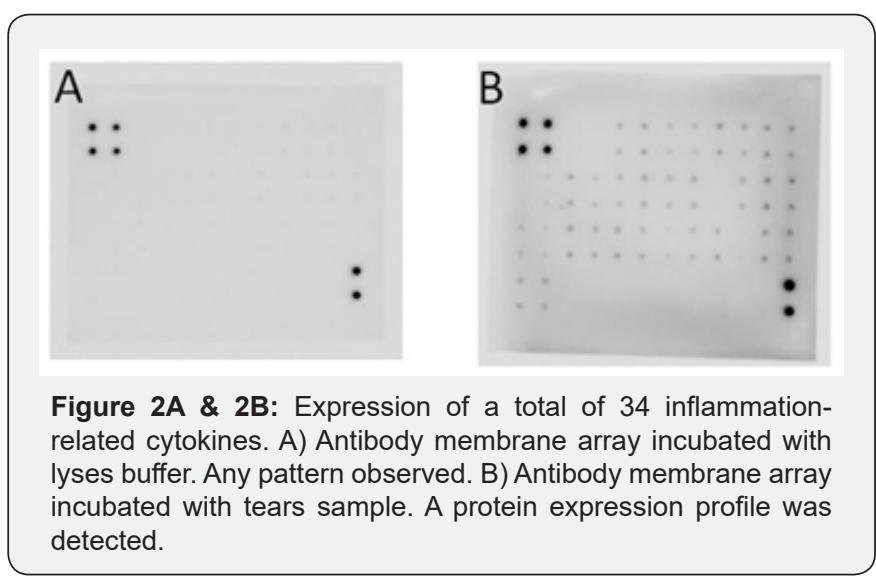

Mini array technique was used to find, other compounds of tears, any cytokine or inflammatory mediators in human tears as a potential biomarker in eye disease. One array membrane was only incubated with lyses buffer (negative control). Another array membrane was incubated with a tear sample. Results showed in Figure 2A no expression profile, were only detected positive control spots in the upper left and lower right corners of the membrane. However, Figure 2B, membrane incubated with a tear sample, showed a protein expression profile. Cytokines and chemokines deregulation can support the onset of eye disease linked to chronic inflammation, tumorigenesis, and autoimmunity. Most of these molecules are related to the eye pathogenesis; they should also be kept in mind when discussing treatment strategies.

\section{Conclusion}

In conclusion, our results indicate that antibody array technique is a very useful tool to study, in tear samples, the relative expression of a great variety of cytokines in order to identify those that are up/down-expressed in eye diseases. Furthermore, this is 
a non-invasive screening technique which can be used to identify potential biomarkers of eye diseases.

Finally, it can open a new perspective to identify new inflammatory markers, so as to use them as possible targets for the development of new pharmacological approaches.

\section{Acknowledgment}

This work was supported by the grant FBG (Fundació Bosch i Gimpera) 60021.

\section{References}

1. Borrebaeck CA, Wingren C (2014) Antibody array generation and use. Methods Mol Biol 1131: 563-571.

2. Huang W, Whittaker K, Zhang H, Wu J, Zhu SW, et al. (2018) Integration of antibody array technology into drug discovery and development. Assay Drug Dev Technol 16(2): 74-95.

3. Rivera Del Alamo MM, Díaz Lobo M, Busquet S, Rodríguez Gil JE, Fernández Novell JM (2018) Specific expression pattern of tissue cytokines analyzed through the Surface Acoustic Wave technique is associated with age-related spontaneous benign prostatic hyperplasia in rats. Biochem Biophys Rep 14: 26-34.

4. Keren Z, Braun Moscovici Y, Markovits D, Rozin A, Nahir M, et al. (2009) Depletion of B lymphocytes in rheumatoid arthritis patients modifies IL-8-anti-IL-8 autoantibody network. Clin Immunol 133(1): 108-116.

5. Hinchliffe TE, Lin ZT, Wu T (2016) Protein arrays for biomarker discovery in lupus. Proteomics Clin Appl 10(6): 625-634.
6. Huang Y, Zhu H (2017) Protein array-based approaches for biomarker discovery in cancer. Genomics Proteomics Bioinformatics 15(2): 7381.

7. Reverter JL, Nadal J, Ballester J, Ramió-Lluch L, Rivera MM, et al. (2011) Diabetic Retinopathy Is Associated with Decreased Tyrosine Nitrosylation of Vitreous Interleukins IL- $1 \alpha$, IL-1 $\beta$, and IL-7. Ophthalmic Res 46(4): 169-174.

8. Careba I, Chiva A, Totir M, Ungureanu E, Gradinaru S (2015) Tear lipocalin, lysozyme and lactoferrin concentrations in postmenopausal women. J Med Life 8(Spec Issue): 94-98.

9. Rishi P, A Dhami, Biswas J (2016) Biopsy techniques for intraocular tumors. Indian J ophthalmol 2016 64(6): 415-421.

10. Singh AD, Biscotti CV (2012) Fine needle aspiration biopsy of ophthalmic tumors. Saudi J Ophthalmol 26(2): 117-123.

11. Bradford MM (1976) A rapid and sensitive method for the quantification of microgram quantities of protein utilizing the principle of protein-dye binding. Anal Biochem 72: 248-254.

12. Laemmli UK (1970) Cleavage of structural proteins during the assembly of the head of bacteriophage T4. Nature 227(5259): 680-685.

13. Schnetler R, Gillan WDH, Koorsen G (2012) Immunological and antimicrobial molecules in human tears: a review and preliminary report. S Afr Optom 71(3): 123-132.

14. Hessen M, Akpek EK (2014) Dry eye: an inflammatory ocular disease. J Ophthalmic Vis Res 9(2): 240-250.

\section{Your next submission with Juniper Publishers will reach you the below assets}

- Quality Editorial service

- Swift Peer Review

- Reprints availability

- E-prints Service

- Manuscript Podcast for convenient understanding

- Global attainment for your research

- Manuscript accessibility in different formats

( Pdf, E-pub, Full Text, Audio)

- Unceasing customer service

Track the below URL for one-step submission https://juniperpublishers.com/online-submission.php 